\title{
A database approach to cross selling in the banking industry: Practices, strategies and challenges
}

Received (in revised form): 1st December, 2003

\section{Kin-nam Lau}

is currently an associate professor of marketing at the Chinese University of Hong Kong, Shatin, Hong Kong. His research interests include customer relationship management (CRM), data mining, management information systems (MIS), and marketing research. He has served as CRM consultant in five leading banks in Hong Kong. His major publications have appeared in the Journal of Management Information Systems, Journal of Marketing Research, Journal of Database Marketing, Journal of Classification, Decision Science, and the European Journal of Operations Research. He obtained his PhD from Purdue University and taught in North Dakota State University, before returning to Hong Kong.

\section{Haily Chow}

is the Head of Knowledge Management in Hang Seng Bank where she leads and spearheads the research and development of the bank's customer knowledge base and deployment of business intelligence to drive an integrated sales and marketing process. As a seasoned marketing practitioner with over 15 years of experience in retail banking, she previously worked for Chase Manhattan Bank and HSBC, where she was responsible for marketing research and database management. She received her Bachelor in Business Administration from the Simon Fraser University, Canada.

\section{Connie Liu}

had a number of years of marketing and business development experience prior to joining the Chinese University of Hong Kong, first as a researcher and then as a PhD student. Her current research topics are CRM and information mining. She holds a Master's degree in e-commerce from the Chinese University of Hong Kong and a Bachelor's degree from the University of Bristol.

Abstract Competition among banks all over the world is getting increasingly fierce and the effectiveness of traditional marketing campaigns is reducing at an alarming rate. To maintain competitiveness, banks have to adopt new approaches to improve marketing and operational efficiency. This paper focuses on the issues pertaining to the database approach to cross selling, which is believed to be the key value-enhancer in the future. Since Hong Kong is always regarded as the 'mirror of the future' for China, the authors use Hong Kong as an example to illustrate the practices, strategies and challenges of cross selling in the banking industry. Stories of cross selling in Hong Kong today will soon be retold in China with its 1.3 billion retail customers, and may significantly influence future cross selling operations and strategies there.

Dr Kin-nam Lau Dept of Marketing, Faculty of Business Administration, K.K. Leung Building, The Chinese University of Hong Kong, Shatin, Hong Kong.

Tel: +852 2609 7766; Fax: +852 2603 5473; e-mail: knlau@baf.msmail. cuhk.edu.hk

\section{INTRODUCTION}

People see and hear bank advertising on television, radio, newspapers and magazines every day. However, does anyone know how much additional revenue these advertising activities actually bring in? The traditional above-the-line advertising is commonly known to be effective in image building and acquisition when there is no other channel for reaching new customers. On the other hand, database marketing uses 
the economic 'footprints' left in the databases to infer the current situation about customers and hence make use of it to achieve the four main goals of bank marketing: 1) cross selling, 2) retention, 3) increase utilisation, 4) acquisition and 5) cost/service quality. Compared with advertising, database marketing is a more targeted approach that requires fewer resources, and the results can be relatively easier to measure. At this time of economic turmoil, and under the constant threat of merger and acquisition, it is particularly critical for banks all over the world to be able to maintain competitiveness through effective cost control. Database marketing thus provides an alternative way of looking at the business dynamics of banks.

In this paper, the authors focus on the issues pertaining to cross selling, as it is believed to be the key value-enhancer in the future. Hong Kong was chosen as an example to illustrate the practices, strategies and challenges of cross selling in the banking industry for two reasons. First, Hong Kong is not only one of the key financial centres in the world but also a very modern city with widespread adoption of electronic payment and internet service. Over 200,000 transactions, worth more than US $\$ 30 \mathrm{~m}$, are processed daily through a centralised bill payment system facilitating electronic payment to a wide variety of merchants ranged from public utilities, government/statutory organisations, banks and telecommunications companies to educational institutions and charity organisations over the telephone and the internet. The number of smart cards in circulation actually outnumbers the local population, and electronic money has become an inseparable part of the public transport system in Hong Kong. Such rapid developments in electronic commerce have generated millions of transactions, all being recorded in different databases within the banking sector. These are the economic 'footprints' of an individual customer and they can be used to deduce customer preferences, behaviour, affordability, financial needs, etc. Against this background, Hong Kong is considered an ideal market to implement the database approach to cross selling. More importantly, the cross selling framework discussed in this paper will not end here because Hong Kong has been a gateway to China since the 1980s. Hong Kong successfully introduces Western business practices, management concepts and human capital to China, and it is always regarded as the 'mirror of the future' for China. The cross selling stories in Hong Kong today will soon be retold to China's 1.3 billion customers, and will significantly influence her future cross selling operations and strategies.

This paper is organised as follows. First the overall view on cross selling in Hong Kong is presented, then the two major approaches to cross selling, namely the active mode and the passive mode, are discussed and illustrated with examples. The last two sections are a summary of the future trends of cross selling and the conclusion.

\section{CROSS SELLING FRAMEWORK IN HONG KONG}

The massive volume of customer intelligence generated from databases within the banking system enables banks to revolutionise the sales and marketing processes and to achieve more effective selling of products and services. ${ }^{1-4}$ Figure 1 shows a schematic overview of how cross selling activities should be initiated through these channels to best leverage what is understood about customers.

There are, in general, two approaches to cross selling, ie selling in active or passive mode. Active selling refers to 


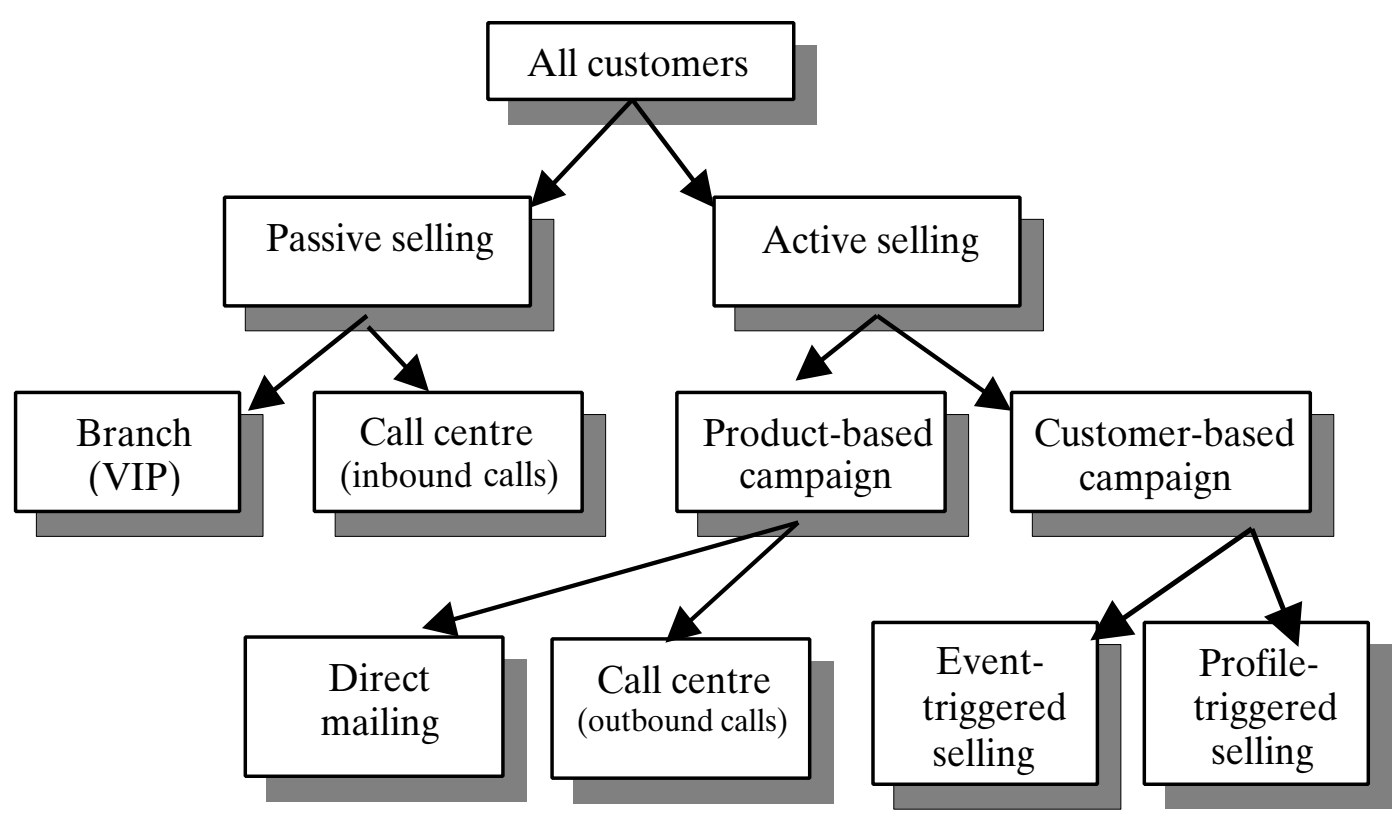

Figure 1: Cross selling approaches in the banking industry in Hong Kong

proactive sales efforts initiated by the bank to identify the right prospects for its products and services. This can be in the form of product-based or customer-based campaigns. The product-based campaign is to find the right customers for a particular product whereas the customer-based campaign is to sell the right products to a particular customer according to the needs indicated by his/her profile or most current event. On the other hand, passive selling refers to capturing the cross selling opportunity arising from a customer coming to the branch or contacting the call centre for services on his or her own initiative.

The banking industry has engaged in active selling for decades and it has a proven track record bringing in revenue of millions and millions of dollars every year. In view of a volatile market and a decreasing budget, the new trend in active selling is to move towards organising all the sales activities based on customer intelligence from the bank's databases. With the help of data mining techniques, banks can now understand their customers a lot better; and with this understanding comes a more personalised service approach. Active selling can now be targeted towards a particular group of customers, such as customers of the same life stage or occupation, and product bundles can be designed for each particular group based on their preferences, needs and affordability. There is no doubt that targeted campaigns are more likely to yield a higher response rate and incur lower running costs, however, the major paradigm shift in selling is caused by the availability of customer information in the area of passive selling.

Hong Kong, which is characterised by an unprecedented high concentration of bank branches, has relied heavily on the extensive branch network to deliver banking services. Given the thousands of interactions conducted at branches or call centres daily, there are tremendous opportunities for banks to undertake passive selling, an increasingly important 
sales practice in the competitive banking arena. The beauty of passive selling is that it involves virtually no additional cost by comparison with other active selling methods such as direct mailing. The customers are also more receptive to the sales talk right after a satisfactory service experience. Nevertheless, it is simply not possible for frontline personnel to concurrently review the need of each customer while delivering the service within the short span of two to three minutes. This said, suitable product and service offerings must be determined in advance for each customer prior to their visit to the branch.

In the past, banks simply did not have enough detailed information to make any useful distinction between different types of customers. Fortunately, with advances in technology and increased popularity of electronic payment, ${ }^{5}$ specific information on each customer can now be extracted from internal, as well as external, databases. Different aspects of one's personal life such as lifestyle, purchase preference, family structure, affordability and even loyalty to the bank can now be reviewed using an array of data mining techniques based on the most current transactional data. The result is a comprehensive system to match different products to each customer with customised communication messages and to offer the 'next product to offer (NPO)'. ${ }^{6}$

\section{THE ACTIVE APPROACH TO CROSS SELLING}

Active selling includes both product-based selling and customer-based selling. While the former - generally known as 'campaign management' pushes a particular product to the existing customers, the latter attemps to sell the right products to a customer according to customer needs.

\section{Product-based selling: Campaign management}

The product-based marketing campaign ${ }^{7}$ has been a winning formula for selling financial services for many years and mass advertising, promotional events and sponsorship remain the mainstream tactics. Recently, targeted direct mailing and telemarketing have also become popular means to acquire new customers in a proactive manner. For example, direct mailers offering pre-approved credit cards, usually gold or platinum cards, have proven effective for soliciting upgrade applications from selected customers. Customers are also found to be receptive to calls from the bank selling simple general insurance products over the phone. The hit rate can be as high as one in ten. Nevertheless, response rates to direct mailers have been on a downtrend in the past decades, causing the customer acquisition costs to soar. Accenture research showed that responses to credit card direct mailers dropped from 2.8 per cent in the early 1990 s to 0.6 per cent in $2000 .^{8}$ In other words, it is four times more expensive to acquire a new customer now than before. This change in profit dynamic has forced marketers to take a serious look at what really makes a campaign work. Three factors are believed to have contributed to the decline in campaign response rate: competition, product life cycle and proliferation of direct mailing.

The competition among banks over the small market of Hong Kong is second to none in the world. Following the rapid expansion of retail banks over the last decade, the volume of direct marketing campaigns has been growing exponentially. The use of direct mailers has reached such an abusive level that it has lost the appeal to consumers.

Assuming each customer has accounts in three banks, and every customer receives an average of one piece of bank 
communication each week, together with mailers from other aggressive marketers such as telecoms, department stores, beauty centres, etc, it is not surprising that an average consumer will be exposed to more than seven pieces of direct mail in a week ie 'not a day goes by without a direct mailer'. This intensive exposure to the same medium has caused most communications to appear commonplace and to fail to arouse purchase interest.

Product innovation is also a double-edged sword. In the continuous attempt to meet and exceed customer expectations, banks have been faced with short product life cycles whereby a new product coming on to the market is quickly replaced by another better product in three to six months' time. Competitive advantage at product level is becoming more and more difficult to sustain as customer loyalty diminishes. Given such unfavourable market conditions, what can the bank marketer do? This paper examines possible improvements in terms of information, people and organisation.

\section{On information and data mining technology}

Target marketing, as the name implies, starts and ends with the identification of the right targets. Data mining techniques ${ }^{9}$ such as logistic regression, neural networks, decision trees and market basket analysis, have emerged as the key technologies for analysing the causation or association relationship among hundreds of variables in order to explain and predict the product choice for millions of customers in the database. Latent class modelling and clustering algorithms can be used to derive actionable marketing segments. Factor analysis is applied to develop product bundles based on observed customer choices. Moreover, each potential customer is also evaluated according to his/her expected incremental cost and profit before the prospect list is finalised. These computational models are important and necessary in the cross selling process, but not sufficient to produce good prediction results without quality input data. The current trend in Hong Kong seems to focus more on the application of such sophisticated techniques in database marketing than the continuous enhancement of the data quality. Most banks already have data warehouses to store massive amounts of raw data for years, but the self-declared demographic data in the warehouse is often outdated and the transactional data has not yet been fully cleansed. While the database still suffers seriously from missing value problems, the data mining specialists take the easy approach and rush to build propensity models with partial or immature information, even though common sense would say that targeting accuracy depends more on updated and quality information than the mathematical techniques per se. If the bank were willing to spend substantial resources to undertake more rigorous and extensive data cleansing on all types of static and transactional data before mining, marketers could have understood the customers better and the targeting plan could be more precisely formulated. Moreover, marketers yearn for an understanding of customers' buying psychology; in-depth learning about customers' rationales for rejecting the current offer will provide valuable insights to identify the 'hot buttons' that motivate purchase decisions. For marketers who have awakened to the importance of collecting feedback data, the effort of delving into the millions of customer interactions taking place at different touch points is hindered by the lack of an easily accessible response 
tracking system. Therefore, there is an imminent need to establish a learning mechanism for collecting data on the objections encountered in the telemarketing process. Knowing the objection reasons, such as 'no need', 'too expensive' or 'already have it', can allow marketers to fine tune their targeting logistics and minimise repetitive mistakes in future campaigns.

\section{On people}

The skills sets of marketers also pose a fundamental problem. Database analysts are experts at uncovering 'statistically significant' relationships out of tera-bytes of data and identifying emerging trends in growing or diminishing customer relationships. Many of them have a good understanding of the database and analytics, but not quite such a good understanding of marketing. Little wonder today's database marketing practice is full of classic cases of 'getting an exact solution to a wrong question'.

Database specialists tend to emphasise the application of sophisticated analytics to deliver the 'optimal' marketing solution whereas often approximate answers to the appropriate questions will suffice to yield significant increase in revenue. The following key marketing questions must first be answered in order to predict a successful purchase:

- Can he/she afford the product? (affordability)

- Does he/she need the product? (needs)

- Has he/she bought a similar product from competitors? (competition)

- Should any discount be offered? (price)

- How can we persuade him/her to buy it? (communication message)

The current major role of database analysts in the business intelligence units of most banks in Hong Kong, however, is to generate cross selling lists according to customer affordability and need only, instead of extracting answers to the above questions for bank marketers to design the best one-to-one offer. As a result, a qualified customer may decline the offer because it is the wrong product (ie already bought), the wrong price or the wrong message. On the other hand, it is also not uncommon for product managers who are in full control on all the '4Ps' of the marketing mix and database analysts who focus on customer targeting to work independently in their 'area of expertise' on a marketing campaign. The segregation of duties points to a common pitfall — product adoption is assumed to be a simple function of customer need, and the marketing mission is hence to ascertain who has the need for a certain product so that the organisation can sell to them from its 'assembly line'.

\section{On organisation}

Call centres have emerged as one of the banks' main channels for delivering customer service. While both in-house and outsourced call centres can be found, the latter seem to have gained in popularity in recent years. This trend is spurred not only by the potential saving in running costs, but also the changing role of outbound telemarketing capabilities in achieving successful cross selling. In today's highly competitive market, every good customer is likely to be approached by more than one bank; hence the critical success factors are speed and volume. One might argue that the increasing number of telemarketing calls is approaching an abusive level similar to that of direct mailing, which is, sadly, inevitable, especially when banks are competing to increase their market share fast. However, with proper targeting criteria, telemarketing offers 
two things that direct mailing cannot: effectiveness and speed. In order to support massive contact of a large number of customers faster than the competitors, more and more banks have opted for outsourcing to large and well-established teleservice vendors to take advantage of their scale and technology. A typical large call centre employs more than 1,000 agents, all with proper training and knowledge in a variety of financial products. To match this kind of scale is near impossible for any in-house call centre, even those in very large banks.

The large volume of calls being made each day from an outsourced call centre, allows it to accumulate experiences and expertise on a wide variety of products and, therefore, enables the creation of a vast database on the details of each call and analyse the interrelationship between key variables such as customer profile, product characteristics, call time, agent profile and rejection reasons. Based on the most updated knowledge deduced from the large scale database, the call centre is able to consult the bank on the best approach to maximising campaign effectiveness through value-added services, such as preparing sales scripts tailor-made for certain customer segments, matching a particular type of sales agent to customers with certain characteristics (eg contacting young customers by an opposite sex agent) and recommending different approaches to handling objections for different groups of customers.

To sum up, targeting alone accounts for only 20 per cent of campaign success. A relevant sales message, seamless integration of front- and back-end operations and objection handling tactics are powerful determinants of the overall campaign effectiveness. Nowadays banks view every customer interaction as a learning opportunity, and the capability to integrate this learning into the value chain will help customise a relevant service proposition - the sticky element - to preserve customer relationships. ${ }^{10}$

\section{Customer-based selling}

Customer-based selling is the selection of product(s) for individual customers based on their needs and preferences. There are two types of customer-based selling: event-triggered and profile-triggered selling.

\section{Event-triggered selling}

There are two broad types of events that point to specific selling opportunities. External events are incidents happening outside of the banking environment; such incidents can be captured from external sources (eg from newspapers) and subsequently be used in the selling of banking products. Internal events, on the other hand, are incidents which can be detected within the database of the bank. Such incidents include the maturity of a time deposit, change of home address, redemption of a mutual fund etc. Bank marketers are familiar with the concept of event-based marketing, the most common application being a birthday programme when a bank sends a special token of appreciation to valued customers on their birthday. However, the previous objective was more focused on customer service and creating a good image for the bank. Nowadays, these events can also be turned into effective sales opportunities on a one-to-one basis. There follow two examples from Hong Kong.

Being a densely populated city with over 7 million inhabitants, Hong Kong possesses a strong internal demand for property. Before the financial crisis dampened prices, there was an active 
first-hand market for new property projects offering outstanding estate facilities and modern conveniences. Quality properties at prime locations were in great demand. Flats were usually sold in phases and over-subscription was common; price fluctuations could be phenomenal. Under the buoyant market, potential home buyers were required to submit an initial deposit to the property developer and the allotment of the right to purchase was drawn by ballot. A ballot winner list containing an incomplete record of Hong Kong Identification Numbers would then be posted in the local newspaper to inform selected homebuyers to go to the sales office at a designated time for flat selection. Some aggressive banks in Hong Kongs with an eye on this golden opportunity, have taken the initiative to match the list of ballot winners against the bank's own database to identify customers with a 'home purchase signal'. The prospect list can be generated within hours and the sales script and special incentives are also ready before the close of day so that telemarketing mortgage services to these prospective homebuyers can kick-off on the next business day. This event-based programme has proved highly effective in soliciting new mortgage loans. In the days before database marketing, the only way of reaching potential customers was passive selling - setting up sales kiosks around the showroom, fighting with other banks to get business from customers - which is both labour intensive and cost ineffective. The use of database marketing on first hand property is by far the best example for illustrating how data can improve the bank's operation and maximise the revenue by making it faster and more targeted.

Another example is the cross selling of wealth management products triggered by initial public offering (IPOs). The
Hong Kong stock market is very active in listing new companies listed on either the main board or the Growth Enterprise Market (GEM), a very similar structure to the New York Stock Exchange and Nasdaq. There is a general favourable sentiment towards IPOs as they are often conceived as a 'sure-win' opportunity the stock price is expected to go up after an IPO under most circumstances and new shares can be sold after a short period to reap profit. As a result, new investors with limited experience or even no previous experience are keen to participate in IPO subscription. Leveraging on this special event, the more aggressive players have launched customised promotions based on the unique needs of retail investors during the post-IPO period. The IPO participants are sub-divided into two target groups - those who have successfully subscribed to the new shares and those who failed. For those novice investors who have successfully subscribed to the shares, the immediate need is to set up a securities account to deposit the physical shares to pave the way for easy selling in the near future. While there are hundreds of service providers in the market, some banks offer a direct selling service (with no holding period ' $\mathrm{T}+0$ ') for selected new stock to entice new customers to open securities accounts. For the group with failed subscriptions, the immediate need is to deposit the refund cheque back into the savings account. This will be the right time to promote low risk investment products or high interest savings plans to customers with idle funds on their hands. Both the successful and failed IPO subscribers can be tracked through matching of the share allotment directory and advanced analysis of customers' account transactions; a customer-winning strategy can then be implemented accordingly. 
Table 1: Common event-triggered cross selling programmes in Hong Kong

\begin{tabular}{|c|c|c|c|}
\hline Event Type & Event & Sources & Marketing actions \\
\hline \multicolumn{4}{|l|}{ External } \\
\hline & IPO & $\begin{array}{l}\text { Newspaper, HKEx website } \\
\text { listing }\end{array}$ & $\begin{array}{l}\text { Cross selling investment-related products. } \\
\text { Product selection based on the amount } \\
\text { subscribed and the risk level of the } \\
\text { subscripted stock }\end{array}$ \\
\hline & 1st hand property & $\begin{array}{l}\text { Newspaper, website of } \\
\text { property developer }\end{array}$ & $\begin{array}{l}\text { Cross selling of mortgage-and-home } \\
\text { related insurance }\end{array}$ \\
\hline & Tax payment & Government & Cross selling of tax loan \\
\hline \multicolumn{4}{|l|}{ Internal } \\
\hline \multirow[t]{5}{*}{$\begin{array}{l}\text { Life stage } \\
\text { related }\end{array}$} & Marriage & $\begin{array}{l}\text { Credit card transaction, } \\
\text { eg marriage consultant, } \\
\text { wedding dress hiring } \\
\text { service }\end{array}$ & $\begin{array}{l}\text { Cross selling of credit card, loans and } \\
\text { insurance }\end{array}$ \\
\hline & Birthday & Customer declaration & $\begin{array}{l}\text { Send birthday card and discount coupons } \\
\text { to build up relationship }\end{array}$ \\
\hline & Pregnancy & $\begin{array}{l}\text { Transaction with } \\
\text { gynaecologist/obstetrician/ } \\
\text { observation by branch staff }\end{array}$ & $\begin{array}{l}\text { Cross selling of education fund and } \\
\text { child-related products }\end{array}$ \\
\hline & Graduation & $\begin{array}{l}\text { Year joining college } \\
\text { affinity card }\end{array}$ & $\begin{array}{l}\text { Increase card utilisation, cross selling of } \\
\text { insurance products }\end{array}$ \\
\hline & Retirement & Pension payment & $\begin{array}{l}\text { Cross selling of funds and medical } \\
\text { insurance }\end{array}$ \\
\hline \multirow[t]{2}{*}{$\begin{array}{l}\text { Utilisation } \\
\text { related }\end{array}$} & Idle cash & $\begin{array}{l}\text { Loan pay-off/redemption of } \\
\text { investment fund/insurance } \\
\text { policy/time deposit maturity }\end{array}$ & $\begin{array}{l}\text { A guarantee fund with higher interest rate } \\
\text { than the current time deposit can be } \\
\text { offered to the customers }\end{array}$ \\
\hline & Attrition & $\begin{array}{l}\text { Drop in assets/activities/ } \\
\text { product }\end{array}$ & Tailor-made retention actions \\
\hline \multirow[t]{2}{*}{$\begin{array}{l}\text { Contact } \\
\text { change } \\
\text { related }\end{array}$} & $\begin{array}{l}\text { Change of } \\
\text { address }\end{array}$ & Customer declaration & $\begin{array}{l}\text { If the customer is moving to a better } \\
\text { location and/or bigger place, upgrade his } \\
\text { existing product(s) and/or cross sell } \\
\text { wealth management products }\end{array}$ \\
\hline & Change of job & $\begin{array}{l}\text { Change in payroll, change } \\
\text { of office phone number }\end{array}$ & $\begin{array}{l}\text { If the customer has an increase in salary, } \\
\text { upgrade his existing product(s) and/or } \\
\text { cross sell wealth management products }\end{array}$ \\
\hline
\end{tabular}

On the other hand, internal events are classified into three main categories: life stage related, utilisation related and contact change related. Table 1 shows some examples of the most common event-triggered cross-selling programmes in Hong Kong. Event-triggered marketing can be very effective and the challenges lie in finding ways to capture the customer events inside and outside the bank and to automate knowledge-driven selling programmes to maximise the cross selling opportunities.

\section{Capturing external events - Detection}

Not all customer events can be found within the in-house database. Events such as property purchase, IPOs, passing a professional exam etc are not available from the traditional banking database. Nonetheless, the detection of external data sources can give rise to extremely useful event-driven selling opportunities. These 'hot lists' come from various third parties, some of them from the public domain. With the increasing concern over privacy, the use of these personal data are subject to stringent regulatory requirements. Marketers have to obtain proper consent from both the institution and the subject concerned before they can undertake marketing activities with these prospects. One of the common tactics for bypassing the privacy issue is for two organisations to collaborate in swap-base promotions. Frequent travellers are a valuable segment to credit card 
companies, therefore, many banks prefer to leverage on the customer base of frequent-flyer programmes such as Asia Mile and Star Alliance to recruit new card holders. Moreover, the fact that millions of customer interactions take place every day through the branches also enables the branch network to play the role of an important channel for collecting customer events. Without asking customers directly, branch staff can help to observe and record the life stage change of a pregnant customer or a customer's travel destination during the purchase of traveller's cheques.

\section{Capturing internal events - Data refresh}

In addition to knowing what events to look for, time-to-market is another important theme in event-based marketing. As each event represents a specific selling opportunity within a time window, banks will be competing fiercely on their ability to refresh the data frequently to capture these passing opportunities. For example, the competition for mortgage loans has reached white heat, with banks accepting down payments by credit card. The down payment, which is 10 per cent of the property price, will normally be settled by combining the credit limits from two credit cards. In other words, the two banks will be competing for the potential mortgage business against time and the first one to detect down payment from the credit card transaction will take a lead in cross selling mortgage services to this prospective home buyer. By the same token, the timeliness of updated transaction data also plays a critical role to retain idle funds from, for example, a recent redemption of an investment fund. Banks need to take prompt action to secure the idle funds before they are poached by other competitors.

\section{On automation and execution}

Detection of customer events is an important first step to successful event-based selling. Yet it will yield little benefit to a bank if the events are only captured on a one-off basis. The event detection logics must be fully automated so that the sales opportunity can be captured as soon as the signal appears. Take the fact that the Hong Kong population is aging. According to the Population Policy report, a quarter of the local population is expected to be aged 65 or above by 2031. ${ }^{11}$ The growth in the retiree population caused by prolonged lifespan has made retirement a critical life event signalling new financial needs. On realisation of this business potential, many banks have taken the initiative to identify the customers aged between 55 and 58 and a marketing campaign is launched to cross sell new services targeted at these potential retirees. No doubt this is good work and able to generate new business for the bank, yet the campaign could well be orchestrated with more precision. Instead of taking everybody in the age band of 55-58 as a broad-based target, banks can build a system to monitor more closely the retirement date of individual customers so that each of them will receive custom communications right after, if not within, his or her month of retirement. The key is to conduct a thorough review on customers' payroll history so that the system can automatically look for monthly pension payments. Once the pension transaction is tracked, a cross selling programme based on the customer's unique profile will be initiated. This will either be in the form of a direct mailer or telemarketing with different messages for the mass and affluent segments. Another unique example in Hong Kong is the purchase of a second property in the southern part of China where the retirees 
can enjoy a better quality of living (bigger space, more facilities) at an affordable price. There will be a good demand for mortgage services if the bank can offer a one-stop solution for mainland properties. Affluent customers may already have several properties on hand, and the selling message will focus on luring them to invest in instruments with stable income eg retail bonds, real estate investment trusts (REITs). The bank can also offer estate management services for this high net worth segment.

Technology has a strategic role to play in addition to a seamless cooperation between the database marketer and sales channels (branch and call centre).

Database marketers are responsible for coordinating the process at the back-end, so that the right customer is picked out from the massive database and matched up with the right product. A sales prompt will then be passed to the front-line at the right time so that the sales channels are empowered with all the necessary intelligence to conduct and close the sale. The corresponding sales script is generated automatically based on the customer profile, product preference, life stage and lifestyle characteristics etc. The entire sales process is automated so that personalised sales actions - who to sell what and when - take place at the precise moment of truth and are scheduled well in advance.

\section{Profile-triggered selling}

In addition to keeping track of life changing events, in-depth understanding of customers' profiles can also lend itself to effective cross selling. Currently, banks' marketing programmes tend to be designed based on customers' demographic and socio-economic characteristics such as gender, age, occupation, total assets etc. The effectiveness of these profile parameters has been dwindling, as it is by and large common information known to all banks. The secret of success lies in gaining access to proprietary knowledge based on the known customer profile to facilitate personalised active selling. This will require a transformation of key profile characteristics including life stage, job nature and behaviour. While the first two are familiar attributes to most marketers, behaviour refers to transactional data such as cash withdrawal from automated telling machines (ATMs), cheque deposits, credit card purchases, internet banking etc. The process to redefine these profile parameters is described in greater detail below.

Based on a well-defined profile indicating customer's product preference and affordability, banks can take advantage of product bundling to provide a 'one-stop shop' service to suit a wide range of needs for customers with the same profile. For example, a professor who works in the university tends to have a relatively stable and high income. $\mathrm{He}$ or she is not likely to be very familiar with the investment environment and, at the same time, tends to be more conservative in his or her investment strategy. A relevant service bundle should comprise of an integrated account offering a preferential interest rate for deposits reaching a certain level together with a discount in subscription of guaranteed funds. A note of caution is that this kind of bundling effort requires the cooperation and balance of interest between different departments and product managers, which will not be met without resistance.

The biggest challenge associated with profile-based selling is to address the fundamental question of how to identify customer profile? As discussed previously, lifestage marketing, which is by far the most successful profile-based selling approach, is often carried out based on a 
few basic parameters ie gender, age, marital status and service utilisation. Often, such information is both outdated and incomplete so that no meaningful understanding of the individual customer can be further derived. The important key here is data cleansing. ${ }^{12}$ There is no short cut to the clean-up process; arduous and resource-intensive data cleansing and standardising processes are required to attach meaning to massive volumes of seemingly trivial information. This commitment to undertake intensive data cleansing has deterred many organisations from reaping the full benefit of highly targeted cross selling. As an illustration, the following shows how banks find different ways to solve their cleansing problems.

\section{Life stage}

Life stage profile can be ascertained from both external and internal sources. Census data forms an important basis for projecting the life stage information of customers. Based on the bi-census data, a bank can construct a high-level life stage profile of their customers down to street block level. To add precision to this projected framework, enrichment logistics are developed to continuously update a life stage profile based on inference as learned from customers' declarations. For example, a married woman aged 40 living at a particular housing estate is highly likely to have two children under the age of 12 according to the latest census. She will be assumed to be married with children until the system records that she has turned down an offer of an education savings plan because she was single. This reason for declining is fed into the customer relationship management (CRM) system to trigger an update on her profile so that she will be excluded from future marketing of child-related products.

\section{Job nature}

Phone number cleansing is a useful best practice for overcoming the pitfall of missing occupation. This is the process of matching the office phone number with the prefixes of phone numbers of large companies and corporations. This might be unique in the Hong Kong situation, since the trend is to reserve a range of consecutive phone numbers with the same prefix to be used within a company. This makes possible the deduction of the corresponding company name from a given office phone number and, hence, the industry a customer belongs to. In some cases, occupation can also be deduced by combining the social class and the profile information with the industry information for a customer. For example, if a customer's office phone number is found to have the same prefix as a hospital; if the social class of this customer is high (deduced from residential address); and he is middle aged; then it is very likely that this customer is a medical doctor of senior rank working in the hospital. No doubt it is labour intensive to construct a full phone directory of all companies classified into different industries, but the information obtained from it is highly valuable. Not only does occupation information reflect the affordability and need of the individual, it also serves as an indication of the likelihood of a long-term commitment (measured by the stability and prospect of the industry), which is particularly crucial in selling insurance and investment funds.

In addition, analysis of frequent ATM transactions provides additional insight on occupation. For example, a customer with frequent transactions conducted at the ATMs within the premises of a government building at lunchtime, indicates that this customer is likely to be a civil servant. By the same token, occupations with a strong geographic 
Table 2: Example of profile-triggered selling

\begin{tabular}{|c|c|c|c|}
\hline Profile type & Profile & Characteristics & Possible cross selling actions \\
\hline \multirow[t]{3}{*}{ Occupation } & $\begin{array}{l}\text { Medical } \\
\text { professionals }\end{array}$ & $\begin{array}{l}\text { Risk of contracting disease } \\
\text { from work }\end{array}$ & $\begin{array}{l}\text { Extra insurance coverage on special } \\
\text { contagious diseases }\end{array}$ \\
\hline & $\begin{array}{l}\text { Teacher/civil } \\
\text { servant }\end{array}$ & $\begin{array}{l}\text { Stable and relatively high } \\
\text { income }\end{array}$ & $\begin{array}{l}\text { Special integrated accounts with higher } \\
\text { interest rate and/or lower service to lock } \\
\text { in their fund. Then cross sell } \\
\text { investment-related product to them, } \\
\text { possibility with long term commitment }\end{array}$ \\
\hline & $\begin{array}{l}\text { Architects, civil } \\
\text { engineers and } \\
\text { surveyors }\end{array}$ & $\begin{array}{l}\text { High risk professionals, } \\
\text { relatively high income but } \\
\text { less stability }\end{array}$ & $\begin{array}{l}\text { Insurance-related product with accident } \\
\text { and medical component and/or short term } \\
\text { investment product such as securities } \\
\text { trading }\end{array}$ \\
\hline \multirow[t]{2}{*}{ Life stage } & $\begin{array}{l}\text { Middle class } \\
\text { working mothers }\end{array}$ & $\begin{array}{l}\text { Concern about children's } \\
\text { education but do not have } \\
\text { too much time or } \\
\text { knowledge to invest }\end{array}$ & $\begin{array}{l}\text { Education funds and special children's } \\
\text { accounts with gifts }\end{array}$ \\
\hline & Near retirement & $\begin{array}{l}\text { Going to have a lump sum } \\
\text { retirement payment and loss } \\
\text { of medical protection } \\
\text { from company }\end{array}$ & $\begin{array}{l}\text { Retail bonds, guarantee funds and } \\
\text { medical-related insurance }\end{array}$ \\
\hline \multirow[t]{5}{*}{ Behaviour } & Frequent traveller & $\begin{array}{l}\text { Frequent credit card } \\
\text { payment in foreign } \\
\text { currencies }\end{array}$ & $\begin{array}{l}\text { Travel, life and medical insurance } \\
\text { products }\end{array}$ \\
\hline & Gambling & $\begin{array}{l}\text { Customers who frequent } \\
\text { race courses/casinos but } \\
\text { have a good repayment } \\
\text { history in credit card/ } \\
\text { mortgage/loans }\end{array}$ & $\begin{array}{l}\text { Increase credit limit, tax loan, personal } \\
\text { loan }\end{array}$ \\
\hline & $\begin{array}{l}\text { Fashion } \\
\text { conscious }\end{array}$ & $\begin{array}{l}\text { Frequent credit card } \\
\text { purchase from fashion } \\
\text { retail outlets }\end{array}$ & Increase credit limit, personal Ioan \\
\hline & Price conscious & $\begin{array}{l}\text { Sudden increase in credit } \\
\text { card spending during } \\
\text { merchant promotion period }\end{array}$ & $\begin{array}{l}\text { Special discount product bundle or } \\
\text { services, higher interest deposit }\end{array}$ \\
\hline & $\begin{array}{l}\text { Luxurious life } \\
\text { style }\end{array}$ & $\begin{array}{l}\text { Frequent spending with } \\
\text { high-end merchants }\end{array}$ & $\begin{array}{l}\text { High-end products or accounts with } \\
\text { special privileges }\end{array}$ \\
\hline
\end{tabular}

association, such as a military force working near a remote army campsite or university employees working on campus, can be mapped.

\section{Behaviour}

The best behavioural analysis comes from credit card transactional data. All credit card merchants can be classified according to their business nature and degree of luxury, hence each transaction can tell us whether the customers are fashion conscious, frequent travellers, etc. This information can be used in the design of communication messages and product packages. For an overview on the methodology and concept behind data cleansing and fusion, please refer to Figure 2. Table 2 above shows some examples of profile-triggered selling.

\section{THE PASSIVE APPROACH TO CROSS SELLING}

Passive selling is the bank taking the opportunity to promote a product while servicing a customer in a branch or on a telephone. This is particularly important in the environment of Hong Kong, given the dense population and very high concentration of banks. The larger the bank, the more it finds it difficult to sell to all its customers actively. Under a limited marketing budget, only selected 
Table 3: Example of if-then-else rules used to determine selling sequence

\begin{tabular}{ll}
\hline Criteria & Product to offer \\
\hline If a customer has: & Life insurance \\
- less than $\$ 20,000$ on deposit and & \\
- no time deposit and & \\
- life stage is either single or married with young children & Guarantee funds \\
If a customer has: & \\
- time deposit $>20,000$ and & \\
- life stage is either married with older children or near retirement & \\
- no gambling behaviour &
\end{tabular}

customers with high profit potential will be approached through active selling, whereby cross selling to the vast majority will be taken care of in a passive mode.

As discussed above, in order to facilitate passive selling, a complete one-to-one marketing plan with specific product, price and communication messages must be compiled for each customer before he/she approaches the bank for service. To achieve this, it is first necessary to observe or deduce customers' needs, affordability, potential and behaviour patterns from the database to create a set of marketing variables. Having created the marketing variables, the next step of data preparation and planning is the integration of company strategy. From the cross selling aspect, it is primarily product matching and price setting. In the process of determining which product to sell to which type of customer at what price through which channel, many criteria must be set before the final answer can be derived (eg customers with long-term time deposit should be offered guaranteed funds; whereas overdraft facilities could be a useful offering to customers with moderate gambling behaviour). These criteria can be translated into computing rules (ie if-then-else rules) and solved by using the marketing variables.

There are other rules such as cross sell and de-duplication rules. The cross sell rule eliminates the chance of selling the same product to customers who have already bought it by offering other alternatives. The de-duplication rule disqualifies customers who are not likely to purchase the product, eg customers with negative equity are not likely to purchase anything that does not allow mobility of resources. The above example is, of course, a simplified version of the real life situation in any bank. There can easily be more than 100 products in a bank, all with specific features, target customers, requirements and profit margin. A careful review of all the products will generate a myriad set of rules, which can, in turn, be used to determine the final offer to each customer. Figure 2 shows an overall view of the above-mentioned NPO process.

The full implementation of the entire framework will call for an information-rich interface to deliver these personalised selling plans (NPO) to the frontline sales staff. Possible applications include those listed below.

VIP list: in some banks, a full-scale implementation of the NPO plan is not yet available due to limitations in technology and resources. The application of the NPO plan is limited to the creation of a VIP list at individual branch level. A list of potential customers calculated using the NPO algorithm would be delivered to the branch where customers most frequently visit. Bank representatives can hence be able to 


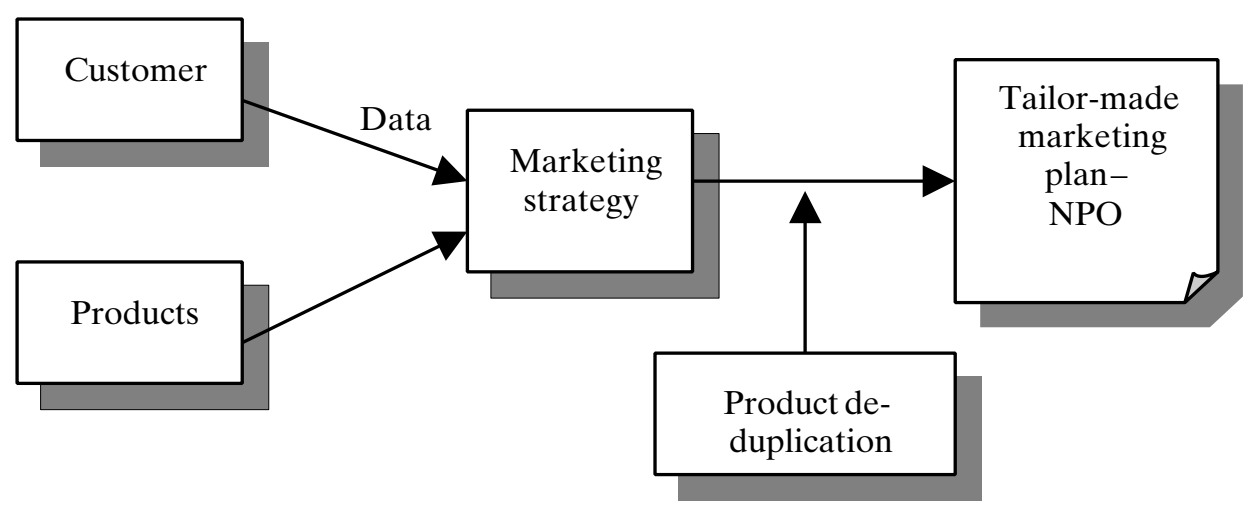

Figure 2: Overview of 'next product to offer'

contact the customers and cross sell to them according to the information provided on the list.

In-bound calls: most retail banks set up their own telephone banking service centre to provide a convenient channel for enquiries and banking transactions.

There is no better time to push a product to a customer than after he/she has been served and while having a good feeling towards the bank's service. All a bank representative has to do is simply follow the selling sequence and instructions generated by the NPO system.

The major hindrance is again the political issue. Due to the current organisational structure, product managers are responsible for his/her own profit centre, and hence must compete to gain priority for their respective products. The implementation of the NPO system can be seen as a step towards a customer-orientated organisation and the beginning of a cultural change. In Hong Kong, the most common and nearest to a full-scale implementation of such a system is the generation of VIP lists for each branch to facilitate selling.

\section{FUTURE TRENDS AND STRATEGY}

This cross-selling framework will be augmented with increased inputs from the individual customer level in the overall sales process. In this conclusion, we provide a glimpse of some of the changes anticipated in the 'rules of the game' as marketers become more sophisticated in the deployment of database-driven initiatives.

\section{Householding strategy}

Cross-selling programmes are expected to move beyond the individual customer level to focus on the banking needs of a household. This household selling concept makes good business sense as major financial decisions — such as buying a new property or education planning for children - are, in real life, joint decisions within the household. Paying due attention to all key decision makers will improve the receptiveness to banks' selling efforts. Moreover, the existing relationship with some of the household members can lend itself to effective 'relationship-based' cross selling. A member-get-member programme is proven to be far more effective at targeting family members than friends or relatives in Hong Kong, given proper incentive. In order to facilitate selling to a household, relationships between the family members must be ascertained. Capturing of relationship data can be solicited through direct declaration or database matching. It is a good practice to incorporate in customer 
communication materials an area for customers to state needs and contacts of other members of the family. This should be complemented by some ongoing incentive for household subscription. For banks with a large retail franchise, various family members may already have an account within the same bank. The household relationships can be uncovered by matching residential addresses and home telephone records. The efficiency and accuracy of the matching process can be greatly enhanced by the implementation of address and telephone number cleansing exercises.

\section{Product strategy}

The theme underpinning new product innovation is to provide more choices for customers. Instead of launching new stand-alone products or services, banks are expected to offer a variety of service packages to cater for the different needs of customers. The proliferation of service bundles will eventually evolve to a buffet concept whereby customers can customise their own service package, ie 'pick $\mathrm{k}$ out of n'. This one-to-one product will not only meet the exact needs of the customers it will also facilitate open negotiation on price and, as a result, help curb customers from bargain hunting from place to place. The mortgage business is the first one to adopt this open business model to fend off white heat competition on price. The mortgage interest rate has fallen by 500 basis points from $\mathrm{P}+2.5$ per cent in 1997 to $\mathrm{P}-2.5$ per cent in 2003. Major mortgage banks offer a wide range of mortgage service options on repayment method ie straight line, step-up, interest only, reducing balance, deferred repayment, mortgage overdraft etc as well as monthly and fortnightly mortgage repayment periods.
Some more aggressive players are also introducing innovative mortgage accounts which integrate savings, payroll, current and mortgage accounts under one roof for total financial management. This combo-account allows flexible partial repayment at any time without any limitation, ie no additional interest or penalty. On the other hand, customers are allowed to redraw additional payment anytime via cheque or ATMs. Deposits in the account will bring higher yield than the normal savings rate (daily interest on loan outstanding), the account also comes with a payment holiday option to meet short-term liquidity need.

In addition to acquiring new business, banks taking a lead in offering more choices to customers can learn from these 'self-revealed' preferences and help formulate other product/service offerings in the future.

\section{Pricing strategy}

When product differentiation diminishes, monetary reward becomes a determining factor influencing a customer's purchase decision. In the Hong Kong market, customers will receive upfront cash rebates when they commit on a mortgage loan. Credit card holders will also receive cash rewards based on card spending. More widespread applications of cash rewards are envisaged and banks are expected to offer rewards not only to their sales staff but also the customers to incentivise new business. Turning your customer base into a sales force is no new concept, and consumers are familiar with member-get-member programmes. To take this one step further, banks can consider offering rewards at both the personal and the business level eg referral of family members or associated companies will all be rewarded.

In addition to activities that generate sales directly, those that produce sales 
leads for follow-up will also be rewarded. The ultimate goal is to establish a clear linkage between the efforts contributing to new business; all the initiatives leading to the set up of a healthy pipeline of new businesses as well as keeping customers from leaving should be rewarded. Though it may have cost implications on business initially, banks are expected to benefit from improved customer satisfaction and a stronger bonding with their customers in the long run.

\section{New business models}

In the face of commoditisation, banks will redefine their role as providers of financial products and services to offer a total solution for customers. This change in service proposition will lead to more banks broadening their involvement in the provision of non-financial services as a means to strengthen customer relationships.

\section{The bank as the marketing agent to merchants}

Credit card companies are pioneers in this area, offering wide-ranging lifestyle benefits in dining, shopping, travelling, leisure activities, etc to sustain usage and loyalty to their cards. As credit card usage becomes more popular, major card issuers have amassed tremendous data on customer spending patterns and card usage behaviours, which provide rich sources for analysis of an individual's life stage and lifestyle profile. The information is not only valuable for the marketing of financial products and services; it can be equally useful in pinpointing potential customer segments for non-financial products and services. The bank can now leverage this new customer knowledge to launch highly cost-effective joint promotion programmes with selected merchants targeted at specific customer segments. Few banks in Hong Kong have already ventured to offer a database marketing service to support highly targeted business promotion. A distributor of collector items used to distribute quarterly catalogues to solicit mail orders. Based on the past five years' experience working with different list rental vendors, the mailing size is on average 200,000 and the response rate is 0.1 per cent generating sales turnover of $\mathrm{HK} \$ 2 \mathrm{~m}$. By leveraging on the bank's database which provides a detailed profile of customer segmentation, this regular catalogue is targeted with much greater efficiency. With only half of the mailing size, the response rate has doubled and total sales generated slightly exceeded last year's catalogue. Above all, the reduction in mailing quantity has generated cost savings of $\mathrm{HK} \$ 0.5 \mathrm{~m}$ in postage and production of promotional materials.

\section{The bank as a consultant to the merchant}

A similar success story to that mentioned above will inevitably lure merchants to partner with banks in direct marketing initiatives. In due course, we shall see more banks embracing vertical expansion in this direction, offering not only database marketing services but also a one-stop consulting service from customer selection, and design and production of customer communications all the way to delivery and fulfilment for their business customers.

\section{The bank as a buying agent for retail customers}

By providing the above-mentioned services to the merchants, banks are, at the same time, providing added-value service to their customers by bringing 
them what they need at the time they need it and at a reasonable price.

\section{CONCLUSIONS}

In the process of establishing the cross selling framework the authors describe in this paper, there are two major issues that play a pivotal role to the success of this new business practice.

First, the mission of cross selling should not be limited to targeting, but should embrace a total view of targeting (3Cs) and offer (4Ps). The authors envisage a surge in corporate resources invested in initiatives to acquire in-depth understanding of customers' relationships with the bank and with competitors. The efforts should go beyond traditional measurement of customer wealth in the bank or general satisfaction with the services, to a new focus on the total share of wallet, performance benchmarking and reason for objection or attrition. This new learning about customers should then be integrated into the product development process to ensure the 4Ps are designed to meet customer needs.

There will also be a heightened awareness of data integrity, and banks have come to realise the importance of data cleansing and that quality control is a necessary evil. Especially in China, declared information from customers is not necessarily truthful and has not been verified and, unlike Hong Kong, there is no comprehensive knowledge base of addresses for the major cities, making data cleansing a near impossible task to be undertaken with reasonable accuracy. Fortunately, however, the ID (personal identification number) of Chinese citizens contains detailed profiling information such as birthday, birth place etc and can be used to supplement the missing information.

Another area is organisation silos, ${ }^{13}$ which sabotage the effectiveness of the customer-centric cross selling model. Despite making significant strides in the CRM journey in the area of technology deployment, a majority of banks are still predominantly organised in a product-based management structure. Product managers are fully accountable for the control of marketing investment, planning of customer solicitation activities and delivering the overall bottom line. For the few forward-looking organisations with a customer management infrastructure, these 'customer departments' tend to play a subservient role responsible for spending their share of the annual budget in 'loyalty' programmes. In many cases there is neither a clear guiding strategy to determine what must be offered to fulfil the most imminent customer needs nor a thorough review of the effectiveness of the proposed programmes. A not too uncommon yet saddening scenario is for a bank to launch two promotion programmes at the same time, both offering privileges to existing customers. The first one may be a credit card (product) promotion offering travel packages at an exceptionally low price, whereas the other is a travel benefit programme for the high net worth segment (customer), those with total assets over $\mathrm{HK} \$ 1 \mathrm{~m}$ with the bank. This not only represents cannibalisation of internal resources but also sends a confusing message to customers as to the bank's disposition towards customer relationships. In turn it raises the question of which relationship - the product-based or the customer-based - is more valuable to the bank?

Finding an answer to this question is no simple task as there are too many stakeholders involved in the process. Everyone will battle to gain maximum interest from the system without 
considering the benefit for the organisation as a whole. The establishment of a new system can only take effect with the support of a reorganisation of the entire company structure, and this kind of cultural change will require thorough understanding and strong involvement from the top management.

\section{Acknowledgment}

The authors would like to thank the editor and reviewers for valuable and constructive comments to improve the paper.

\section{Disclaimer}

The viewpoints expressed in this paper are those of the authors and by no means indicate the practices or positions of the Chinese University of Hong Kong and/or Hang Seng Bank.

\section{References}

1 Stone, M., Abbott. J. and Buttle, F. (2001) 'Integrating customer data into CRM strategy' in Foss, B. and Stone, M. (eds) 'Successful customer relationship marketing: New thinking, new strategies, new tools for getting closer to your customers', Kogan Page, London.

2 Stone, M. and Foss, B. (2001) 'Strategic data analysis for CRM' in Foss, B. and Stone, M. (eds) 'Successful customer relationship marketing: New thinking, new strategies, new tools for getting closer to your customers', Kogan Page, London.

3 Stone, M., Lowrie, M., Foss, B. and Komolafe, F. (2002) 'The evolution of CRM in banking' in Foss, B. and Stone, M. (eds) 'CRM in financial services, a practical guide to making customer relationship management work', Kogan Page, London.

4 Dibb, S. (2001) 'Banks, customer relationship management and barriers to the segment of one', Journal of Financial Services Marketing, Vol. 6, No. 1, pp. 10-23.

5 Tapp, A., Nancarrow, C., Stone, M., Stubbs, J. and Foss, B. (2002). 'The impact of e-business on financial services marketing and marketers' in Foss, B. and Stone, M. (eds) 'CRM in financial services, a practical guide to making customer relationship management work', Kogan Page, London.

6 Lau, K., Wong, S., Ma, M. and Liu, C. (2003) "'Next product to offer" for bank marketers', Journal of Database Marketing, Vol. 10, No. 4, pp. 353-368.

7 Stone, M., Harris, T. and Foss, B. (2001) 'Campaign management systems and processes' in Foss, B. and Stone M. (eds) 'Successful customer relationship marketing: New thinking, new strategies, new tools for getting closer to your customers', Kogan Page, London.

8 Accenture (2001) 'Insight driven marketing', Accenture research report, p. 12, www.accenture.com/xdoc/en/services/crm/ IDMarketing_Report.pdf.

9 Klosgen, W. and Zytkow, J. M. (2002) 'Handbook of data mining and knowledge recovery', Oxford University Press, New York.

10 Giesen, L. (2003) 'Bridging the channels', Banking Strategies, Vol. 79, No. 3, pp. 34-38.

11 (2003) 'Report of the Task Force on Population Policy', February. pp. 10-11, www.info.gov.hk/ info/population/eng/report_eng.pdf.

12 Pula, E., Stone, M. and Foss, B. (2003) 'Customer data management in practice: An insurance case study', Journal of Database Marketing, Vol. 10, No. 4, pp. 327-341.

13 Rajola, F. (2003) 'Customer relationship management - Organizational and technological perspectives', Springer-Verlag, Berlin-Heidelberg. 